\title{
MONETARY INCENTIVES: USUALLY NEITHER NECESSARY NOR SUFFICIENT?
}

\author{
Andreas Ortmann \\ Ralph Hertwig
}
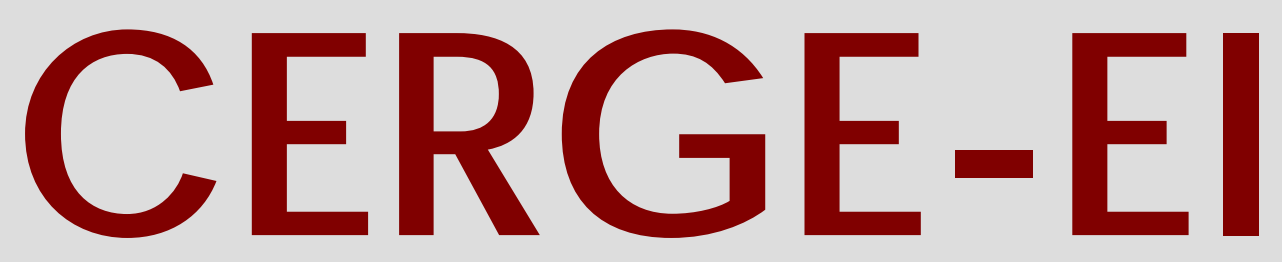

Charles University Centerfor Economic Research and Graduate Education Academy of Sciences of the Czech Republic Ec onomic s Institute 


\title{
Working Paper Series 307 (ISSN 1211-3298)
}

\section{Monetary Incentives: \\ Usually Neither Necessary Nor Sufficient?}

\author{
Andreas Ortmann \\ Ralph Hertwig
}

CERGE-EI

Prague, September 2006 
ISBN 80-7343-103-3 (Univerzita Karlova. Centrum pro ekonomický výzkum a doktorské studium) ISBN 80-7344-092-X (Akademie věd České republiky. Národohospodářský ústav) 


\title{
Monetary Incentives: Usually Neither Necessary Nor Sufficient?
}

\section{Andreas Ortmann ${ }^{\mathrm{a}}$ and Ralph Hertwig ${ }^{\mathrm{b}}$}

\begin{abstract}
Read (2005), in The Journal of Economic Methodology, took our target article in Behavioral and Brain Sciences (Hertwig \& Ortmann 2001) as one point of departure to question the usefulness of monetary incentives for experimental work. In making his case, he misrepresents our analysis, and continues the unfortunate ritual of opportunistic sampling of evidence. As in our target article, we call for an empirical analysis of the impact of monetary incentives.
\end{abstract}

\begin{abstract}
Abstrakt
V časopise The Journal of Economic Methodology použil Read (2005) náš předmětný článek v Behavioral and Brain Sciences (Hertwig \& Ortmann 2001) jako výchozí bod pro zpochybnění užitečnosti peněžních pobídek při experimentální práci. Ve své argumentaci chybně vykládá naši analýzu a dále rozvíjí nešt’astný rituál oportunistického výběru důkazů. Stejně jako v našem předmětném článku i zde voláme po empirické analýze dopadu peněžních pobídek.
\end{abstract}

Keywords: Experimental practices, monetary incentives, financial incentives, rhetorical tactics

JEL classification: C72; C91

Authors' note: We would like to thank Dirk Engelmann, Francesco Guala, and Glenn Harrison for comments on earlier drafts.

${ }^{a}$ Center for Economic Research and Graduate Education, Charles University and Economics Institute, Academy of Sciences of the Czech Republic, Prague,Czech Republic

${ }^{\mathrm{b}}$ Department of Psychology, University of Basel, Basel, Switzerland

Correspondence: Andreas Ortmann, Ph.D., CERGE-EI, Charles University/Academy of Sciences of the Czech Republic, Politickych veznu 7, 11121 Prague 1, Czech Republic, andreas.ortmann@,cerge-ei.cz, Tel: (420)(224 005117 (office) or (49)(173) 6505191 (mobile) 


\section{Introduction}

Although we are delighted to see our article on the differences in the methodological standards and experimental practices of economists and psychologists become a foil for Daniel Read's essay (Read 2005, p. 266, p. 274), we take issue with his interpretation of our findings and conclusions. Because his essay is in the process of becoming a reference of relevance (e.g., Guala 2005, pp. 241-244), we address our objections in detail below.

\section{Misrepresentation of our work}

Our target article in Behavioral and Brain Sciences (Hertwig and Ortmann 2001) examined empirically the consequences of four striking differences in the standards and practices of experimental economists and psychologists, respectively. One of the differences is the use of financial incentives in experimentation. Whereas paying participants according to a clearly defined performance criterion is currently de rigueur for economists, psychologists usually pay a flat fee or grant a fixed amount of course credit. In our article, we analyzed the pros and cons of financial incentives, and we discussed the potential policy implications of our analysis. Read summarized our analysis and policy recommendation as follows:

"In a widely discussed recent paper, for instance, Hertwig and Ortmann (2001) suggested that even psychologists should use incentives whenever possible. [....] In Ortmann and Hertwig's calculus, 'the benefits of being able to run many 
studies do not outweigh the costs of generating results of questionable reliability'. But if incentivised studies merely contain less error (and the reviews of Hogarth and Camerer and Ortmann and Hertwig both suggest this) then it is not an easy manner to compute at what point the benefit from doing more studies outweighs that from doing marginally better ones." (pp. 266, 274)

Based on this reading, Read comes to this conclusion: Financial incentives "are usually neither necessary nor sufficient for achieving our research goals" (p. 272). Moreover, he asserts that "my view is that monetary incentives are not an experimental magic bullet," (p. 266), and "incentives are not a panacea"” (p. 272). Clearly, his conclusion is meant to describe a position counter to ours. He is, however, attacking a straw man of his own construction.

Let us clarify what we said. We do so by reiterating literally some of the conclusions contained in Hertwig and Ortmann (2001) and in our response to the 34 commentaries in the same issue (Hertwig and Ortmann 2001a):

"To conclude, concerning the controversial issue of the effects of financial incentives, there seems to be agreement on at least the following points: First, financial incentives matter more in some areas than in others (e.g., see Camerer \& Hogarth's distinction between judgement and decision vs. games and markets). Second, they matter more often than not in those areas that we explore here (in particular, research on judgement and decision making), which are relevant for both psychologists and economists. Third, the obtained effects seemed to be twofold, namely, convergence of the data toward the performance criterion and reduction of the data's variance. Based on these results, we propose that psychologists in behavioral decision making consider using financial incentives. Although 'asking purely hypothetical questions is inexpensive, fast and 
convenient' (Thaler 1987 p. 120), we conjecture that the benefits of being able to run many studies do not outweigh the costs of generating results of questionable reliability (see Beattie \& Loomes 1997, p. 166).” (Hertwig and Ortmann 2001, p. 395)

Clearly, we did not say what Read claims we say. We did not make an unqualified recommendation regarding the use of financial incentives. Rather, based on an empirical assessment of the available evidence, we proposed to psychologists researching judgement and decision making to consider the use of financial incentives. The reason was that there is empirical evidence that financial incentives make a difference in more cases than not in that particular area (see also Hertwig and Ortmann 2001a and Hertwig and Ortmann 2003). We did not conclude that incentivized studies "merely contain less error". Instead, in our analysis of a 10-year sample of empirical studies published in the Journal of Behavioral Decision Making we found that in the majority of cases where payments made a difference, they improved people's performance (see Table 2 in Hertwig and Ortmann, 2001). We also found that in some of the studies data variability was reduced. Finally, we did not state as a matter of fact that the benefits of being able to run many studies do not outweigh the costs of generating results of questionable reliability. We conjectured, again based on our empirical analysis, that this is the case.

Throughout the target article, and also in our response to the commentators, we advocated a do-it-both-ways heuristic, that is, a methodological approach to experimentation that is ultimately based on empirical evidence. Let us reiterate our proposal: 
"Researchers seeking maximal performance ought to make a decision about appropriate incentives. This decision should be informed by the evidence available. If there is evidence in past research that incentives affect behavior meaningfully in a task identical to or similar to the one under consideration, then financial (or possibly other) incentives should be employed. If previous studies show that financial incentives do not matter, then not employing incentives can be justified on the basis of this evidence. In cases where there is no or only mixed evidence, we propose that researchers employ a simple "do-it-both-ways" rule. That is, we propose that the different realizations of the key variables discussed here, such as the use or non-use of financial incentives... be accorded the status of independent variables in the experiments" (Hertwig and Ortmann, 2001, p. 400).

Far from demanding that "psychologists should use incentives whenever possible," as Read (2005, p. 266, emphasis added) has us advise, we explicitly acknowledged that if past results demonstrate that incentives do not matter researchers can justifiably forego the use of incentives. Our policy proposal is distinctly at odds with experimental economists' standard practice, and we said so:

“Evidently, our policy does not adopt economists' current practices lock, stock, and barrel, nor does it define financial incentives to be the norm in decision experiments. Moreover, the policy does not deny the exciting possibility that less effortful processes can outperform more effortful ones or that decision parameters differ across domains. Of course, this approach also does not deny that incentives other than money may motivate participants. In this context, it is heartening to see that even economists have started to explore the effects of financial incentives systematically, rather than taking them for granted." (Hertwig and Ortmann 2001a, p. 436, second paragraph in R5.1.) 
It should have become clear by now that our position was, and is, not what Read portrays it to be. Rather than continuing the "he said, we said" exercise, however, let us turn to what, in our view, is the key problem of his essay.

\section{Opportunistic sampling}

Debates of methodological standards are typically fraught with deontic statements: One ought to do this and one ought to refrain from doing that (for illustration see the debate about the use of deception that we also review in Hertwig and Ortmann 2001). In this mode of discussion, methodological standards are right or wrong simply because they coincide with one's values and semi-religious beliefs about good experimentation, and not because the empirical evidence supports or contradicts them. Unfortunately, as the decades-old debate about the use of deception in psychology makes abundantly clear, such debates are not likely to go anywhere. This is particularly deplorable when representative empirical evidence is available that could inform such a debate (Ortmann and Hertwig 2002).

Unfortunately, participants in debates on methodological issues typically rely on opportunistic, nonrandom, sampling, a strategy prominently on display in Read (2005): When researchers engage such a sampling approach, they typically include in their analysis, or argumentation, studies that they happen to know of. In other words, they do not bother to compile a representative, or complete set of studies. In fact, review articles exploring the effects of financial incentives that adopted a transparent sampling regime aimed at putting together a representative sample are rare. In Hertwig and 
Ortmann (2001) we provided a template of representative sampling by examining all articles published in the Journal of Behavioral Decision Making in the 10-year period spanning 1988 (the year the journal was founded) to 1997 (the year in which we conducted the analysis). We included 186 studies in the analysis. Of these, $48(26 \%)$ employed financial incentives. Merely 10 of those 48 studies systematically explored the effect of payment. Thus, we achieved a representative, albeit small sample (from $J B D M$ ) speaking to the issue of the effects of financial incentives.

Other frequently cited review studies in this area-for instance, those by Smith and Walker (1993) and Camerer and Hogarth (1999)_adopted an opportunistic sampling approach. In fact, the latter used this very term to characterize their sample. Review studies being thus handicapped, we still—after many years of intense debate of the effects of financial incentives - have relatively little firm knowledge of the actual effects of incentives, the size of the effects, and, perhaps, most importantly, their underlying cognitive and motivational processes.

In light of the evidence, statements such as "incentives never eliminate anomalies" (Read, 2005, p. 266) surely are arguable. If showing that incentives have an impact on an anomaly requires its complete disappearance, then Read may be right. If, however, showing such an impact means demonstrating that incentives reliably attenuate the anomaly relative to a non-incentive condition, then there is considerable much evidence that incentives matter. ${ }^{1}$ More generally, we believe it is time to finally begin to evaluate

\footnotetext{
${ }^{1}$ For instance, Harrison (1994) provides important evidence of the effect of monetary incentives on the Allais Paradox (as, incidentally, did Conlisk 1989), preference reversals, prospect theory, and Bayes' Rule. Cox and Grether (1996; see also the references in that article to the earlier work by Grether and Plott) wrote an important article of the effect of monetary incentives on preference reversals. Plott and Zeiler (2005) question the WTA-WTP gap and the literature on the endowment effect so central to
} 
the impact of financial incentives, their effect sizes, their interaction with other design features (e.g., repetition), and the underlying cognitive and motivational processes on the basis of representative samples. Had Read (2005) done so, his essay on how incentives work might have markedly fostered our knowledge. We do acknowledge that the strategy of representative sampling is not a panacea. For example, there is no guarantee that the articles on which representative sampling has to draw do not reflect fads and fashions, or - maybe more worrisome - inherent distortions in the process of science production (e.g., the well known bias in economics and psychology against simple replication studies). And, of course, sometimes a simple counter example helps to put a particular partisan argument into perspective.

\section{Why incentives and how they work}

Read's (2005) key argument is, first, that incentives work through their influence on "one or more of three factors: (1) cognitive exertion; (2) motivational focus; (3) emotional triggers" (p. 265). Second, he suggests that the intended effects of financial incentives can often be achieved without them, and, in fact, incentives do not guarantee that the intended effects are achieved. Ergo, incentives are "usually neither necessary

prospect theory, as does List (2004). Relatedly, the evidence that there is a huge difference between hypothetical and real buying and contribution decisions is substantive (e.g., Cummings and Harrison, 1994; Harrison and Rutstroem, forthcoming). Cherry, Frykblom, and Shogren (2002) seem to exorcise the alleged altruism in reward allocation decisions (or, "dictator games"), as before them did Rutstroem and Williams (2000), Shapiro (1975), and Mikula (1973). Even the celebrated article by Gneezy and Rustichini (2000; see also the re-analysis in Rydval and Ortmann, 2004), although showing that insultingly low payments might have counterproductive effects, makes it clear that monetary incentives do extract significant effort. Engelmann and Strobel (2000) get rid of the false consensus effect. The title of their paper is programmatic. Although in these papers financial incentives typically interact with other design aspects such as information, anonymity, incentive compatible elicitation mechanisms, or repetition or feedback, they all demonstrate the impact of financial incentives, which, almost universally, reduce the alleged anomalies. 
nor sufficient for achieving our research goals" (p. 272). In what follows, we discuss some of his arguments, in reverse order.

Do monetary incentives act as emotional triggers? If we understand Read (2005) correctly the issue here is whether monetary incentives trigger responses that people are unable to predict while pondering a purely hypothetical scenario. If there were indeed such a prediction gap between a cold (hypothetical consequences) and a hot (real consequences) state, then the utility of merely hypothetical scenarios would be severely limited. Read appears to doubt the existence of such a prediction gap. As one possible instance it, Read discusses Holt and Laury's (2002) finding that risk aversion increases the larger the amount at stake - a tendency that participants in the hypothetical condition appear to be unable to predict. Pointing to the contradictory findings of Holt and Laury (2002) and Kühberger et al. (2002), and questioning the procedures used by the former (but not questioning the latter's; see Kühberger et al. for such a commendable discussion), Read concludes that the effect of payoff magnitude on risk aversion does not appear to be due to a prediction gap. Specifically, Read (2005) makes much of a passage in Holt and Laury's instructions in which they clarified "that your choice in this part has no effect on your earnings and has no effect on what choices will be given to you subsequently; but we are interested in what you would do if you actually faced these choices, so please think about them carefully." (p. 271) Although this formulation may be overkill, some such formulation - lest one wants to run into the kind of reactions reported in Cox and Grether (1996; p. 392, the first full paragraph) seems necessary to communicate to subjects unambiguously that they are in a hypothetical scenario rather than a real one. More generally, in light of the 
overwhelming evidence on hypothetical biases in all kinds of choice and valuation settings (e.g., Harrison 1994; Harrison and Rutstroem in press), we doubt Read's conclusion: "Therefore, the effect of payoff magnitude on risk aversion does not appear to be due to an emotional trigger effect" (p. 271). We admit, however, that the study of Kühberger et al. (2002) poses questions worthy of further investigation.

As regards motivational focus, the second entry in the list of factors through which incentives allegedly work, Read (2005) reiterates the commonly raised objection that financial incentives - conceptualized as extrinsic motives - might drive out intrinsic motivation. As it is, in Hertwig and Ortmann (2001, p. 396) we discussed this issue at length, pointing out that there is no agreement about the evidence and that Cameron and Pierce (1994), and Eisenberger and Cameron $(1996,1998)$ dispute the message of Lepper et al. (1973), the lone reference mentioned by Read and an extreme example of opportunistic sampling. In order to understand how controversial the motivational effects of incentives discussed in psychology are, we encourage readers to attend to the debate between Deci, Koestner and Ryan (1999a, 1999b), Lepper, Henderlong, and Ryan (1999), and Eisenberger, Pierce, and Cameron (1999).

Read (2005) does point out that "the desirability of such crowding out depends on what we want to discover" (p. 269). Although he claims the opposite in the following paragraph, Read acknowledges that Forsythe et al. (1994) found that dictators in the pay decision allocated more to themselves than dictators in the no-pay condition, and suggests, paraphrasing an argument that we made before (see Hertwig and Ortmann 2001, p. 390), that "the interesting result in many studies is not that money can motivate 
decision makers, but that non-monetary motives, such as altruism, can also motivate them." (p. 269) Needless to say, Read never mentions the Cherry, Frykblom, and Shogren (2002) study, or that by Rutstroem and Williams (2000), or Samuelson's astute observation that "each of us is constantly involved in a version of the dictator game, in that we constantly have opportunities to give away the money in our wallets, or anything else that we own. Typically, however, we hold on to what is ours." (Samuelson 2005, p. 87)

Read (2005) concludes his discussion of motivational focus with the following argument:

"If we hypothesize that non-economic motives operate only when there is no money on the table, then the natural way to test this is by comparing incentive with no-incentive conditions. But once the hypothesis has been ruled out, there is no obvious further benefit from partially crowding out non-monetary motives." (pp. 269-270)

Assuming that intrinsic motives, non-economic motives, non-monetary motives are all the same in his book, we note that no one in their right mind and knowing the evidence on ultimatum games, for example, will argue seriously the hypothesis. Surely no one we know claims that non-economic motives operate only when there is no money on the table. And, of course, there is an obvious benefit of "partially crowding out nonmonetary motives": namely, to figure out how robust non-monetary motives such as altruism, fairness and reciprocity are, and to figure out their strength in relation to extrinsic motives! 
As regards cognitive exertion, we learn that "if we are paying people merely because we want them to think harder then incentives should be treated no differently than other ways of achieving this. For instance, incentives are not necessarily better than giving them extra time, writing better instructions, or making them 'accountable' for their choices (Tetlock and Lerner 1999)" (p. 267). True. The operative words, however, are "not necessarily". More fundamentally, the logic of Read's argument is false: Economists pay participants not to make them think harder but to make the consequences of their actions matter (e.g., Smith 1982, p. 931; see also the discussion of Kühberger et al. 2002). Financial incentives therefore may induce our participants to think harder - as the evidence in Glimcher (2003) and Glimcher, Dorris, and Bayer (2004) suggests - but this is not what motivated experimental economists to use financial incentives in the first place.

\section{Conclusion}

Financial incentives are - especially in research on judgment and decision making, as the (opportunistic) sample investigated by Camerer and Hogarth (1999, see also Hertwig and Ortmann, 2003) and the analysis reported in Hertwig and Ortmann (2001) suggests - relevant in more cases than not. For this reason, Hertwig and Ortmann (2001) — addressing psychologists - proposed that they are a good baseline from which to start, unless there is evidence that financial incentives do not matter. More generally, we suggested that researchers employ a simple "do-it-both-ways" rule, thus being able to contrast the results from experimental conditions with and without incentives. Such a practice is likely to rapidly give rise to a database of representative studies that would 
enable experimenters to estimate the effect sizes associated with the presence and absence of incentives, better understand their interaction with other design features (e.g., repetition, framing of instruction) and better understand their cognitive and motivational foundation. Like any other scientific debate, debates about experimental practices ought to be empirically grounded. Caricaturing others' positions and cherrypicking of studies that happen to suit one's methodological priors are counterproductive rhetorical strategies. 


\section{References}

Beattie, J. and Loomes, G. (1997) 'The impact of incentives upon risky choice experiments', Journal of Risk and Uncertainty 14: 155 - 68.

Camerer, C.F. and Hogarth, R.M. (1999) 'The effects of financial incentives in experiments: a review and capital-labor-production framework', Journal of Risk and Uncertainty 19: $7-42$.

Cameron, J. and Pierce, W.D. (1994) 'Reinforcement, reward, and intrinsic motivation: A meta-analysis', Review of Educational Research 64: 363 - 423.

Cherry, T.L. Frykblom, P. and Shogren, J.F. (2002) 'Hardnose the Dictator', American Economic Review 92: 1218 - 1221.

Conlisk, J. (1989) 'Three Variants on the Allais Example', American Economic Review 79: $392-407$.

Cox, J.C. and Grether, D.M. (1996) 'The preference reversal phenomenon: Response mode, markets and incentives', Economic Theory 7: 381 - 405.

Cummings, R.G. and Harrison, G.W. (1994) 'Was the Ohio Court Well Informed in their Assessment of the Accuracy of Contingent Valuation?', Natural Resources Journal 34: 1 - 36 .

Deci, E.L., Koestner, R. and Ryan, R.M. (1999a) 'A Meta-Analytic Review of Experiments Examining the Effects of Extrinsic Rewards on Intrinsic Motivation', Psychological Bulletin 125: 627 - 68.

Deci, E.L., Koestner, R. and Ryan,R.M. (1999b) 'The Undermining Effect Is a Reality After All - Extrinsic Rewards, Task Interest, and Self-Determination: Reply to Eisenberger, Pierce, and Cameron (1999) and Lepper, Henderlong, and Gingras (1999)', Psychological Bulletin 125: 692 - 700.

Eisenberger, R. and Cameron, J. (1996) 'The detrimental effects of reward: Myth or reality?", American Psychologist 51: 1153 - 66.

Eisenberger, R. and Cameron, J. (1998) 'Reward, intrinsic interest, and creativity: New findings', American Psychologist 51: 676 - 9.

Eisenberger, R., Pierce, W.D. and Cameron, J. (1999) 'Effects of Intrinsic Motivation Negative, Neutral, and Positive: Comment on Deci, Koestner, and Ryan (I999)', Psychological Bulletin 125: 677 - 91. 
Engelmann, D. and Strobel, M. (2000) 'The False Consensus Effect Disappears If Representative Information and Monetary Incentives are Provided', Experimental Economics 3: $241-60$.

Forsythe, R., Horowitz, J.L., Savin, N.E. and Sefton, M. (1994) 'Fairness in simple bargaining experiments', Games and Economic Behavior 6: 347 - 69.

Glimcher, P.W. (2003) Decisions, Uncertainty and the Brain: The Science of Neuroeconomics. Cambridge: MIT Press.

Glimcher, P.W., Dorris, M.C. and Bayer, H.M. (2004) 'Physiological utility theory and the neuroeconomics of choice', Games and Economic Behavior 52: 213 - 256.

Gneezy, U. and Rusticchini, A. (2000) 'Pay enough or don't pay at all', Quarterly Journal of Economics 115: $791-811$.

Guala, F. (2005) The Methodology of Experimental Economics. Cambridge: Cambridge University Press.

Harrison, G.W. (1994) 'Expected Utility Theory and the Experimentalists', Empirical Economics 19: 223 - 53.

Harrison, G.W. and Rutstroem, E.E. (in press) 'Experimental Evidence on the existence of hypothetical bias in value elicitation models', in Plott, R.C. and Smith, V.L. (forthcoming) Handbook of Experimental Economic Results. New York: Elsevier.

Hertwig, R. and Ortmann, A. (2001) 'Experimental practices in economics: A methodological challenge for psychologists?', Behavioral and Brain Sciences 24: 383 451.

Hertwig, R. and Ortmann,A. (2001a) 'Money, lies, and replicability: On the need for empirically grounded experimental practices and interdisciplinary discourse', Behavioral and Brain Sciences 24: 433 - 451.

Hertwig, R. and Ortmann, A. (2003) 'Economists' and Psychologists' Experimental Practices: How They Differ, Why They Differ, and How They Could Converge', in Brocas, I. and Carrillo, J.D. (eds), The Psychology of Economic Decisions. Oxford: Oxford University Press.

Holt, C. and Laury, S. (2002) 'Risk Aversion and Incentive Effects in Lottery Choices', American Economic Review 92: 1644 - 55.

Kühberger, A., Schulte-Mecklenbeck, M. and Perner, J. (2002) 'Framing decisions: Hypothetical and real', Organizational Behavior and Human Decision Processes 89: $1162-75$. 
Lepper, M.R., Henderlong, J. and Gingras, I. (1999) 'Understanding the Effects of Extrinsic Rewards on Intrinsic Motivation - Uses and Abuses of Meta-Analysis: Comment on Deci, Koestner, and Ryan (1999), Psychological Bulletin 125: 669 - 676.

Lepper, M.R., Greene, D. And Nisbett, R.E. (1973) 'Undermining children's intrinsic interest with extrinsic rewards: A test of the 'overjustification' hypothesis', Journal of Personality and Social Psychology 28: 129 - 37.

List, J.A. (2004) 'Neoclassical Theory versus Prospect Theory: Evidence from the Marketplace', Econometrica 72: 615 - 25.

Mikula, G. (1973), 'Gewinnaufteilungsverhalten in Dyaden bei variiertem Leistungsverhaeltnis’, Zeitschrift fuer Sozialpsychologie 3: `126-33.

Ortmann, A. and Hertwig, R. (2002) 'The Costs of Deception: Evidence from Psychology', Experimental Economics 5: $111-31$.

Plott, C.R. and Zeiler, K. (2005) 'The Willingness to Pay-Willingness to Accept Gap, the ,Endowment Effect', Subject Misconception and Experimental Procedures for Eliciting Valuations', American Economic Review 95: 530 - 45.

Read, D. (2005) 'Monetary incentives, what are they good for?', Journal of Economic Methodology 12: 265 -76.

Rutstroem, E.E. and Williams, M.B. (2000) 'Entitlements and Fairness: an Experimental Study of Distributive Fairness', Journal of Economic Behavior and Organization 43: $75-89$.

Rydval, O. and Ortmann, A. (2004) 'How Financial Incentives and Cognitive Abilities Affect Task Performance in Laboratory Settings: An Illustration', Economics Letters 82: $385-90$.

Samuelson, L. (2005) 'Economic Theory and Experimental Economics', Journal of Economic Literature 43: 65 - 107.

Shapiro, E.G. (1975) 'Effects of Future Interaction in Reward Allocation in Dyads: Equity or Equality', Journal of Personality and Social Psychology 31: 873 - 80.

Smith, V.L. (1982) 'Microeconomic systems as an experimental science', American Economic Review 72: 923 - 55.

Smith, V.L. and Walker, J.M. (1993) 'Monetary rewards and decision cost in strategic interaction. Economic Inquiry 31: 245 - 61.

Tetlock, P.E. and Lerner, J. (1999) 'The social contingency model: identifying empirical and normative boundary conditions on the error-and-bias portrait of human 
nature', in Chaiken, S. and Trope, Y. (eds) Dual Process Models in Social Psychology. New York: Guilford Press.

Thaler, R. (1987) 'The psychology of choice and the assumptions of economics. in Roth, A.E. (ed) Laboratory experimentation in economics. Six points of view. Cambridge: Cambridge University Press. 
Individual researchers, as well as the on-line and printed versions of the CERGE-EI Working Papers (including their dissemination) were supported from the following institutional grants:

- Economic Aspects of EU and EMU Entry [Ekonomické aspekty vstupu do Evropské unie a Evropské měnové unie], No. AVOZ70850503, (2005-2010);

- Economic Impact of European Integration on the Czech Republic [Ekonomické dopady evropské integrace na ČR], No. MSM0021620846, (2005-2011);

Specific research support and/or other grants the researchers/publications benefited from are acknowledged at the beginning of the Paper.

(c) Andreas Ortmann, Ralph Hertwig, 2006

All rights reserved. No part of this publication may be reproduced, stored in a retrieval system or transmitted in any form or by any means, electronic, mechanical or photocopying, recording, or otherwise without the prior permission of the publisher.

Published by

Charles University in Prague, Center for Economic Research and Graduate Education (CERGE) and

Economics Institute (EI), Academy of Sciences of the Czech Republic

CERGE-El, Politických vězňů 7, 11121 Prague 1, tel.: +420 224005 153, Czech Republic.

Printed by CERGE-EI, Prague

Subscription: CERGE-EI homepage: http://www.cerge-ei.cz

Editors: Directors of CERGE and EI

Managing editors: Deputy Directors for Research of CERGE and EI

ISSN 1211-3298

ISBN 80-7343-103-3 (Univerzita Karlova. Centrum pro ekonomický výzkum a doktorské studium) ISBN 80-7344-092-X (Akademie věd České republiky. Národohospodářský ústav) 
CERGE-EI

P.O.BOX 882

Politických vězňů 7

11121 Praha 1

Czech Republic http://www.cerge-ei.cz 